\title{
The Analysis of Bandung University Students' Ability in Identifying Hoaxes
}

\section{Analisis Kemampuan Mahasiswa Bandung Raya dalam Mengidentifikasi Hoaks}

\author{
Chairunnisa Kamilah ${ }^{1 *}$, Nur Atnan² \\ 1,2 Fakultas Komunikasi dan Bisnis, Universitas Telkom, Indonesia \\ Jl. Telekomunikasi No.1, Terusan Buahbatu-Bojongsoang, Sukapura, Kec. Dayeuhkolot, Bandung, Jawa Barat 40257
}

OPEN ACCESS

ISSN 2541-2841 (online) ISSN 2302-6790 (print)

Edited by: Poppy Febriana

${ }^{*}$ Correspondence:

Chairunnisa Kamilah chairunnisakamilah@stu dent.telkomuniversity.

ac.id

Citation:

Kamilah, $C$ and Atnan, Nur (2021)Analisis Kemampuan Mahasiswa Bandung Raya dalam Mengidentifikasi Hoaks, Kanal,

9(3).

Doi:10.21070/kanal.v9i3.1361

\begin{abstract}
Technological sophistication makes all forms of information available through social media. Information on social media can be uploaded by anyone who owns an account on the social media. This makes many individuals who falsify information for personal or group interests. This study aims to find out whether Bandung Raya students who live in urban areas and are accustomed to accessing social media are able to assess whether the content or articles they see are hoaxes or not. This study uses descriptive quantitative methods by conducting surveys through distributing questionnaires and collecting answers from respondents, namely Bandung Raya students. Data collection was carried out in this study using a questionnaire distributed via google form to 100 samples of students studying in the Bandung Raya area. Based on the results of the analysis that has been carried out on the five indicators to identify hoaxes, the total score of the 22 questions asked is 6,685 and a percentage of $75.96 \%$ which is then entered into the continuum line so that it falls into the "High" category. . Then it can be seen that the respondents were declared capable of assessing or identifying hoaxes through the five indicators used in this study. Bandung Raya students already have the intellectual ability to digital media literacy so that they are able to identify the information obtained.

Keywords: Hoax; Bandung Raya Students; Identification
\end{abstract}

\begin{abstract}
Abstrak
Kecanggihan teknologi membuat segala bentuk informasi bisa didapatkan melalui media sosial. Informasi dalam media sosial bisa diunggah oleh siapa saja pemilik akun di media sosial tersebut. Hal ini menjadikan banyaknya oknum-oknum yang memalsukan informasi untuk kepentingan pribadi ataupun kepentingan kelompoknya. Penelitian ini bertujuan untuk dapat mengetahui apakah mahasiswa bandung raya yang tinggal di wilayah urban tersebut sudah terbiasa mengakses media sosial dan mampu menilai konten atau artikel yang mereka lihat itu merupakan hoaks atau bukan. Penelitian ini menggunakan metode kuantitatif deskriptif dengan melakukan survei online dan mengumpulkan jawaban dari para responden yaitu mahasiswa bandung raya. Pengumpulan data yang dilakukan pada penelitian ini menggunakan
\end{abstract}


kuesioner yang disebar melalui google form kepada 100 sampel mahasiswa yang kuliah di wilayah bandung raya. Berdasarkan hasil analisa yang telah dilakukan pada kelima indikator untuk mengidentifikasi hoaks, maka didapatkan hasil skor total dari 22 item pertanyaan yang diajukan itu sebesar 6.685 dan dalam persentase sebesar $75,96 \%$ yang kemudian dimasukan ke dalam garis kontinum sehingga masuk ke dalam kategori "Tinggi". Maka dapat diketahui bahwa responden dinyatakan mampu menilai atau mengidentifikasi hoaks melalui kelima indikator yang digunakan dalam penelitian ini. Mahasiswa bandung raya sudah memiliki kemampuan intelektual terhadap literasi media digital sehingga mampu mengidentifikasi informasi yang didapat.

Kata Kunci: Hoaks; Mahasiswa Bandung Raya; Identifikasi.

\section{PENDAHULUAN}

Masyarakat saat ini menjadikan informasi sebagai sebuah kebutuhan, karena dengan adanya informasi akan menambah wawasan dalam banyak hal, saat ini berbagai informasi bisa didapatkan dari media sosial. Selain itu dengan kemudahan mengakses informasi di media sosial manapun menjadikan masyarakat dapat mengetahui informasi dari belahan dunia. Dalam buku yang berjudul Komunikasi Antar Personal milik Liliweri (2015:288-289), media sosial menurut Michelle Chmielewski adalah media yang menampilkan tentang berbagai macam hal yang dilakukan dan dikatakan secara bersamaan oleh orang-orang yang berada di penjuru dunia, atau bisa juga dikatakan sebagai alat pertukaran pesan antara komunikator dan komunikan tentang segala sesuatu yang ingin disampaikan secara bersamaan dari berbagai penjuru dunia dengan bantuan teknologi digital.

Informasi dalam buku yang berjudul Literasi Media karangan Dyna Herlina (2019: 150) informasi itu berbeda dengan berita yang merupakan konten yang dibuat sesuai dengan kaidah jurnalistik dan mengacu kepada peristiwa yang dicari dan terorganisir lalu ditayangkan oleh media. Informasi merupakan segala sesuatu yang berbentuk data baik merupakan angka, tulisan, gambar ataupun suara yang mesti diolah agar bisa digunakan untuk menambah wawasan dan dapat digunakan juga oleh seseorang dalam mengambil keputusan ataupun sikap dalam mengambil tindakan.

Ahli komunikasi dari Universitas Indonesia (UI) Muhammad Alwi (dalam Lailatul Utiya, 2017: 3) mengatakan pendapatnya mengenai hoaks yaitu sebagai pemahaman baru yang dibuat sengaja padahal sebenarnya salah dan dikemas dalam bentuk berita yang dimanipulasi isinya. Informasi yang telah diubah kebenaran faktanya agar fakta yang sebenarnya tertutupi untuk kepentingan tertentu ialah pengertian dari hoaks.

Bisa dilihat dalam hasil penelitian yang dilakukan Aziz \& Wardi (2018: 23) jurnalis dari sejumlah media yang meliput kegiatan tahunan HUT RI yang dalam kegiatan tersebut melibatkan transpuan yang diangkat menjadi PNS guru, tetapi jurnalis tetap menyajikan nilai objektif bahwa gender bukan persoalan bagi masyaratak di Madura ketika bisa menempatkan peran di ranah publik, bukan menyajikan hal yang dapat menjadi kontroversi. Dari sini terlihat jelas bahwa hoax itu bukan lahir dari sebuah berita yang diangkat oleh jurnalis, tetapi hoaks lahir dari informasi yang disesatkan oleh oknum-oknum jahat.

Selain itu diartikan juga sebagai pemutarbalikan informasi yang sesungguhnya menggunakan informasi yang dibuat-buat seolah menjadi informasi yang sesungguhnya tetapi tidak bisa dibuktikan akan kebenarannya (Gumgum et al., 2017: 36).

Menurut Dyna Herlina (2019: 137) dalam bukunya yang berjudul Literasi Media, kualitas berita dapat menentukan kualitas kehidupan suatu bangsa, karena apabila media selalu menyampaikan sesuatu yang bersifat hoaks hal ini dapat membuat masyarakat kesulitan untuk memperluas wawasan mengenai fenomena yang sedang terjadi dan dapat mengakibatkan kesulitan untuk membuat keputusan yang baik dalam mengatasi berbagai persoalan individu, sosial dan bangsa. Maka dari itu, Mahasiswa sebagai calon penerus bangsa tentunya harus mampu mencerna informasi berdasarkan keabsahan datanya, mahasiswa harus dapat menilai antara berita yang berisi informasi palsu dengan berita yang berisi informasi asli agar dalam memutuskan suatu persoalan tidak salah langkah.

Mahasiswa bandung raya atau yang bisa disebut juga cekungan Bandung meliputi mahasiswa yang berkuliah di kawasan Kota Bandung, Kabupaten Bandung, Kabupaten Bandung Barat, Kota Cimahi dan Kabupaten Sumedang yang berada di Provinsi Jawa Barat, Indonesia. Mahasiswa ini tersebar di berbagai universitas swasta maupun universitas negeri yang ada di kawasan Bandung Raya, peran mahasiswa saat ini dalam memerangi hoaks sangatlah penting karena pada dasarnya mahasiswalah yang akan berperan sebagai penerus bangsa.

Seperti dalam penelitian Annisa. et. al., (2020: 53) disebutkan bahwa mahasiswa Ilmu Komunikasi UNJ dalam proses mencari informasi mengenai Capres dan Cawapres pada saat Pemilu 2019 itu menggunakan media sosial, hal ini dilakukan karena mahasiswa sudah jarang menggunakan ataupun membuka media lain untuk pencarian informasi. Penelitian lain yang dilakukan oleh Meilinda (2019) disebutkan bahwa peran media sosial sebagai media penyeba- 
ran informasi akademik pada mahasiswa di Program Studi Ilmu Komunikasi Universitas Sriwijaya, hal tersebut dilakukan sebagian besar mahasiswa menghabiskan waktu 510 jam untuk mengakses internet dan media sosial untuk mencari informasi akademik dibandingkan mencari informasi langsung ke bagian dekanat atau rektorat.

Berdasarkan penelitian terdahulu yang telah dilakukan bahwa peran media sosial saat ini sebagai tujuan utama dalam mencari informasi. Hal tersebut sama halnya dengan penelitian ini dilakukan untuk mengetahui kemampuan mahasiswa Bandung Raya dalam mengidentifikasi pada media sosial.

Hoaks ini sangat mudah tersebar karena adanya media sosial yang dengan mudah dan cepat diakses oleh siapa saja yang memilikinya, banyak sekali jenis media sosial yang tersebar di kalangan masyarakat khususnya para mahasiswa yang merupakan generasi milenial yang saat ini sangat dekat dengan kehidupan media sosial. Instrumen yang mendukung komunikasi, jaringan, dan atau kolaborasi secara daring disebut juga sebagai media sosial (Russo, 2008: 22).

Dengan mudahnya hoaks yang tersebar melalui media sosial maka informasi yang tidak valid akan kebenaranya pun akan sangat mudah tersebar, dan hoaks yang tersebar di media sosial pun beragam dan sulit dibedakan dengan berita yang sudah valid kebenarannya. Media sosial itu banyak jenisnya seperti Youtube, Twitter, Instagram, Whatsapp, Line dan media sosial lainnya yang biasanya mendatangkan hoaks tersebut. Menurut Respati (dalam Susilawati, 2017: 48) ada dua faktor yang bisa membuat seseorang akan mempercayai sesuatu yang palsu atau hoaks, karena seseorang akan mudah menerima suatu informasi yang berisikan sebuah pendapat atau sikap yang dimiliki atau bisa dibilang sebagai sebuah opini publik.

Dalam buku yang berjudul Saring Sebelum Sharing karangan dari Simarmata et.al (2019: 37) menyebutkan bahwa ada beberapa ciri hoaks menurut Ahyad yaitu sebagai berikut:

1. Tidak adanya redaksi pemberitaan.

2. Biasanya bersifat sensasional dan dibuat dengan tujuan melebih-lebihkan perasaan agar membangkitkan emosi.

3. Menggunakan kata-kata yang proaktif seperti: Sebarkan!, Lawan!, Rugi kalau tidak klik, Like dan share sebelum terlambat.

4. Berita yang ditayangkan sebenarnya sudah expired.

5. Biasanya memiliki unsur yang diskriminatif untuk memojokan kelompok lain.

Mahasiswa sebagai generasi muda dinilai masih menjadi penerima hoaks dalam penyebaran informasi di media sosial karena dalam mengakses internet mahasiswa dinilai tinggi atau sering menggunakannya, sebenarnya dalam penggunaan internet itu baik asalkan disertai dengan kecerdasan intelektual. Selain itu dilansir pula dari pikiran-rakyat.com adanya informasi yang mengatakan bahwa akan ada pembuatan sim kolektif atau tanpa tes diseluruh Indonesia p- ada tanggal 1 sampai 2 Maret 2020 merupakan informasi hoaks yang sampai ke daerah Bandung Raya dan hal itu dibantah langsung oleh Polresta Bandung yang mengimbau masyarakatnya agar tidak termakan isu hoaks tersebut (Febriani, 2020).

Riyanto \& Hastuti (2017: 32) menyatakan bahwa sebenarnya mahasiswa itu sudah mampu dan memiliki kemampuan dalam mengenali ciri-ciri hoaks yang marak muncul di media sosial dan menjadikannya viral. Mahasiswa dapat mengenali bagaimana bentuk usaha untuk mempengaruhi dan membagikan kembali hoaks atau opini publik yang mengandung ujaran kebencian terhadap seseorang maupun sekelompok orang. Dari sini harusnya mahasiswa mampu menilai dan mendeteksi untuk mencari tahu tentang kebenaran sumber sehingga sebuah berita yang berisikan informasi dapat dipercaya, dari mulai sumber yang menerbitkan berita dan kapan berita tersebut dimuat, sehingga hal ini akan membuat mahasiswa mampu untuk membedakan dan terhindar dari hoaks.

Hasil dari sosialisasi dan pelatihan jurnalistik yang diadakan oleh Kelompok Kerja (Pokja) Wartawan Gedung Sate dan Ikatan Jurnalis Televisi Indonesia (IJTI) Jawa Barat kepada para mahasiswa dan masyarakat umum di Lapangan Gasibu, Bandung, pada hari Sabtu 28 Desember 2019 dinyatakan bahwa mahasiswa Bandung Raya dapat dinilai rendah dalam mengidentifikasi berita palsu dan hoaks padahal mahasiswa Bandung Raya hidup atau tinggal di wilayah urban yang sumber literasi sudah mudah diakses dan didapatkan oleh para mahasiswa, seharusnya dalam hal ini mahasiswa paham dan dapat membedakan atau mengidentifikasi hoaks yang tersebar di media sosial.

Identifikasi merupakan sebuah cara untuk mengenali sesuatu, menurut Kamus Besar Bahasa Indonesia kata identifikasi berarti tanda diri, penentuan identitas seseorang, atau proses meniru figur yang diidamkan. Tetapi dalam hal ini yang di identifikasi merupakan bentuk informasi atau berita bohong yang biasa dikenal dengan istilah hoaks. Menurut Aliansi Jurnalis Independen (AJI) (dalam Pakpahan, 2017: 482), kemampuan untuk menilai sebuah berita dapat dilihat dari lima faktor utama, antara lain sebagai berikut:

1. Penilaian judul menurut Ariwibowo (2017: 4), judul yang memiliki kesan mengandung perbuatan tindakan kejahatan atau bersifat menghasut biasanya merupakan tanda hoaks, karena judul yang baik itu dibuat apa adanya berdasarkan peristiwa yang terjadi bukan malah membuat masyarakat ikut memberikan dukungan atau simpatinya. Judul yang bersifat provokatif akan membuat pembacanya merasa dipengaruhi dan merasa diajak turut serta dalam suasana atau keadaan yang terdapat dalam isi berita atau informasi yang disampaikan oleh penulis, hal ini menjadikan kondisi tidak netral.

2. Penilaian situs menurut Wirawan \& Wibisono (2017: 1), untuk membedakannya dapat dilihat dari penggunaan alamat resmi seperti co.id ataupun org dan memiliki etik dalam penyampaian beritanya biasanya website yang resmi akan memenuhi syarat itu, selain itu website yang 
resmi akan memiliki pihak yang bertanggung jawab untuk melakukan penerbitan dari website tersebut sehingga memiliki sumber yang kredibel.

3. Penilaian konten, dalam konten yang disajikan itu biasanya menandung sebuah opini, informasi yang menjadi isi dalam sebuah berita yang baik akan memiliki penulisan atau tata tulis yang baik dan santun sehingga mudah dipahami oleh para pembacanya. Sedangkan apabila terdapat isi berita yang cara penulisannya dan penyampaiannya tidak jelas bisa dipastikan isi berita tersebut tidak dibuat oleh orang yang bertanggung jawab dan bisa juga dipastikan bahwa berita tersebut palsu.

4. Penilaian foto, dalam sebuah informasi yang menampilkan sebuah foto/gambar seringkali menggunakan foto/gambarnya yang menipu walaupun tujuannya sebagai ilustrasi tetapi tidak relevan dengan judul atau caption yang ditampilkannya. Karena memang gambar saat ini sudah mudah untuk di edit dari gambar aslinya untuk menciptakan kesan lain dari dalam gambar tersebut. Namun untuk membedakannya foto atau gambar yang asli akan lebih serasi dan enak dilihat oleh mata bisa dibilang tidak ada yang mengganjal di mata, biasanya gambar palsu kurang serasi apabila dilihat oleh mata.

5. Penilaian Sumber berita, berita yang berasal dari akun yang baru dibuat dan bersifat abal-abal yang tidak jelas sumbernya bahkan tidak memiliki penanggung jawab bisa dinilai sebagai hoaks, karena hal ini menjadi penanggung jawab adanya berita tersebut disebarkan oleh situr tertentu (Riyanto \& Hastuti, 2017: 32).

Terdapat penelitian sebelumnya dari Fatkhrurahman (2019) yang membahas mengenai kemampuan mahasiswa Universitas Tempatan menilai hoaks yang menggunakan indikator penilaian berdasarkan judul, situs, konten, foto/gambar dan sumber yang tertera pada sebuah informasi yang dibaca. Dalam penelitian tersebut menjelaskan bagaimana peran mahasiswa menghadapi hoaks yang dihubungkan dalam jiwa kewirausahaan, karena semakin maraknya oknum yang memanfaatkan hoaks untuk memasarkan produk jualannya, penelitian tersebut dilakukan agar mahasiswa mampu menilai hoaks dari segi kewirausahaan. Dan dalam penelitian tersebut didapatkan hasil bahwa mahasiswa Universitas Tempatan dinilai berada dalam kategori sedang ketika menilai sebuah informasi itu dikatakan hoaks.

Penelitian lain yang dilakukan Fitriana (2019) yang membahas tentang menilai hoaks kepada mahasiswa Universitas Lampung dengan menggunakan indikator yang berbeda dengan penelitian sebelumnya, yaitu menggunakan teori persepsi dengan indikator stimulus, organism dan response. Dan dari penelitian terssebut didapatkan hasil bahwa mahasiswa Universitas Lampung mengetahui hoaks dari media massa seperti facebook dan twitter.

Berdasarkan penelitian terdahulu tersebut memiliki perbedaan dan kesamaan dengan penelitian yang dilakukan yaitu dilakukan sama untuk meneliti hoaks sebagai objek utamanya, dan terdapat perbedaan pada objek kajian peneliti- an. Maka dari fenomena dan penjelasan diatas, peneliti akan melakukan penelitian yang berjudul "Analisis Kemampuan Mahasiswa Bandung Raya dalam Mengidentifikasi Hoaks'.

Untuk memahami kembali seperti apa cara mengidentifikasi hoaks dengan menggunakan indikator dari Aliansi Jurnalis Independen (AJI) yaitu penilaian berdasarkan judul, situs, konten, foto/gambar dan sumber yang tertera pada sebuah informasi yang dibaca, penelitian ini dilakukan kepada mahasiswa yang berdomisili di wilayah Bandung Raya.

Peneliti ingin mengetahui sejauh mana kemampuan mahasiswa Bandung Raya yang tinggal di wilayah urban dan sudah sangat erat dengan kehadiran teknologi ini dalam menilai sebuah informasi yang dibaca apakah termasuk kedalam hoaks atau bukan.

\section{METODE PENELITIAN}

Penelitian menggunakan sampel yang dikerucutkan dari total keseluruhan jumlah mahasiswa Bandung Raya yang didapatkan dari website Pusat Data Pendidikan Tinggi (PDDikti) yang berjumlah 424.042 mahasiswa menjadi 100 mahasiswa. Mahasiswa itu berasal dari 183 perguruan tinggi yang tersebar di wilayah Bandung Raya yang tersebar menjadi 125 perguruan tinggi berada di Kota Bandung, 23 perguruan tinggi berada di Kabupaten Bandung, 8 perguruan tinggi berada di Kabupaten Bandung Barat, 12 perguruan tinggi berada di Kota Cimahi dan 15 perguruan tinggi berada di Kabupaten Sumedang. (https://pddikti.kemdikbud.go.id/pt) diakses 22 Oktober 2020.

Penelitian menggunakan metode teknik sampling untuk mendapatkan jumlah mahasiswa dalam penelitian ini, yaitu dengan cara teknik cluster sampling dan simple random sampling. Metode deskriptif kuantitatif dengan menggunakan kuesioner sebagai data primer. Peneliti ingin mengetahui kemampuan mahasiswa bandung raya dalam mengidentifikasi hoaks yang tersebar di media sosial dengan variabel independen yaitu "Kemampuan Identifikasi" yang digunakan dalam penelitian ini.

\section{HASIL DAN PEMBAHASAN}

Dalam penelitian ini akan menggunakan responden yang merupakan mahasiswa Bandung Raya yang meliputi Kota Bandung, Kabupaten Bandung, Kabupaten Bandung Barat, Kota Cimahi dan Kabupaten Sumedang. Dari populasi tersebut akan diambil 100 sampel sebagai responden untuk diteliti dalam penelitian ini. Data karakteristik responden sebagai berikut : karakteristik berdasarkan jenis kelamin, karakteristik berdasarkan usia, karakteristik berdasarkan domisili kampus.

Karakteristik berdasarkan jenis kelamin pada 100 responden didapat melalui penyebaran kuesioner berupa google form sebanyak $54 \%$ berjenis kelamin perempuan dan $46 \%$ berjenis kelamin laki-laki. Yang dimana 54 orang adalah perempuan dan 46 orang adalah laki-laki. Jadi dapat diketahui bahwa res- 
ponden dalam penelitian ini cukup imbang hanya berselisih 4 orang.

Karakteristik berdasarkan usia pada 100 responden didapat melalui penyebaran kuesioner berupa google form sebanyak $16 \%$ berusia $17-19$ tahun, $80 \%$ berusia $20-22$ tahun dan 4\% berusia 23-25 tahun. Yang dimana responden dengan usia sekitar 17-19 tahun berjumlah 16 orang, responden dengan usia sekitar 20-22 berjumlah 80 orang dan responden dengan usia sekitar 23-25 tahun berjumlah 4 orang. Jadi responden terbanyak dalam penelitian ini berkisar antara usia 20-23 tahun.

Karakteristik berdasarkan domisili kampus pada 100 responden didapat melalui penyebaran kuesioner berupa google form sebanyak $50 \%$ berasal dari wilayah Kota Bandung, sebanyak $32 \%$ berasal dari wilayah Kabupaten Bandung, sebanyak $4 \%$ berasal dari wilayah Kabupaten Bandung Barat, sebanyak 7\% berasal dari wilayah Kota Cimahi dan sebanyak 7\% berasal dari wilayah Kabupaten Sumedang. Yang dimana responden yang berasal dari Kota Bandung sebanyak 50 orang, responden yang berasal dari Kabupaten Bandung sebanyak 32 orang, responden yang berasal dari Kabupaten Bandung Barat sebanyak 4 orang, responden yang berasal dari Kota Cimahi sebanyak 7 orang dan responden yang berasal dari Kabupaten Sumedang sebanyak 7 orang. Jadi dapat diketahui bahwa responden terbanyak dalam penelitian ini berasal dari Kota Bandung sebanyak 50 orang.

Hasil Analisis Deskriptif pada indikator Identifikasi pada Judul ditemukan bahwa kemampuan mahasiswa Bandung Raya dalam mengidentifikasi hoaks melalui penilaiannya pada judul berada dalam kategori tinggi, dengan hasil skor total sebesar 1.091 dari skor ideal 1.600 dan dalam presentase sebesar $68,19 \%$. Dalam hal ini para responden yaitu mahasiswa yang berasal dari Bandung Raya dikatakan mampu dalam mengidentifikasi hoaks melalui penilaian pada judul dalam sebuah artikel yang mereka dapatkan atau mereka baca di media sosial.

Dari penilaian pada judul bahwa sebagian besar responden dapat langsung menilai sebuah artikel berdasarkan judul yang mereka baca itu mengandung informasi palsu/hoaks atau tidak, dapat langsung menilai bahwa judul yang terkesan provokatif cenderung merupakan artikel atau konten yang mengandung informasi palsu/hoaks. Para responden yang menyetujui bahwa artikel yang berisikan informasi palsu/hoaks dapat diidentifikasi hanya dari melihat judulnya saja. Selain itu responden akan membaca judul artikel terlebih dahulu untuk memastikan bahwa artikel yang akan mereka baca merupakan artikel yang mengandung informasi palsu/hoaks atau tidak.

Hasil analisis deskriptif pada indikator identifikasi pada situs/media sosial ditemukan bahwa kemampuan mahasiswa Bandung Raya dalam mengidentifikasi hoaks melalui penilaiannya pada situs/media sosial berada dalam kategori tinggi, dengan hasil skor total sebesar 1.523 dari skor ideal 2.000 dan dalam presentase sebesar 76,15\%. Dalam hal ini p- ara responden yaitu mahasiswa yang berasal dari Bandung Raya dikatakan mampu dalam mengidentifikasi hoaks melalui penilaian pada situs/media sosial dalam sebuah artikel yang mereka dapatkan atau mereka baca di media sosial.

Dari penilaian pada situs/media sosial menunjukan bahwa sebagian besar responden memperhatikan situs atau media sosial yang menerbitkan sebuah artikel untuk memastikan artikel yang akan dibaca itu mengandung informasi palsu/hoaks atau tidak dan menunjukan bahwa hanya sebagian kecil saja responden yang memperhatikan situs atau media sosial yang menyerupai situs/media sosial yang terpercaya (plagiarism) itu biasanya menerbitkan sebuah artikel yang mengandung informasi palsu/hoaks atau tidak. Selain itu responden biasanya memperhatikan isi dari artikel yang mereka baca untuk menilai apakah informasi yang disajikan merupakan informasi palsu/hoaks atau tidak dan menunjukan bahwa sebagian besar responden memperhatikan lembaga yang menerbitkan artikel yang mereka baca pada sebuah situs/media sosial itu, hal ini untuk memastikan isi dari artikel yang mereka baca apakah informasi yang disajikannya merupakan informasi palsu/hoaks atau tidak.

Dan yang terakhir dari sebagian besar responden dalam penelitian ini dapat menunjukan bahwa mereka memperhatikan url atau domain yang menerbitkan artikel yang mereka baca pada sebuah situs/media sosial itu, hal ini untuk memastikan isi dari artikel yang mereka baca apakah informasi yang disajikannya merupakan informasi palsu/hoaks atau tidak.

Hasil analisis deskriptif pada indikator identifikasi pada konten ditemukan bahwa kemampuan mahasiswa Bandung Raya dalam mengidentifikasi hoaks melalui penilaiannya pada konten berada dalam kategori sangat tinggi, dengan hasil skor total sebesar 1.317 dari skor ideal 1.600 dan dalam presentase sebesar $82,31 \%$. Dalam hal ini para responden yaitu mahasiswa yang berasal dari Bandung Raya dikatakan sangat mampu dalam mengidentifikasi hoaks melalui penilaian pada judul dalam sebuah artikel yang mereka dapatkan atau mereka baca di media sosial.

Dari penilaian pada konten menunjukan bahwa sebagian besar responden memperhatikan fakta-fakta yang terdapat pada informasi yang disajikan sebuah artikel, untuk memastikan artikel yang dibaca itu mengandung informasi palsu/hoaks atau tidak, memperhatikan data yang terdapat pada informasi yang disajikan sebuah artikel, untuk memastikan artikel yang dibaca itu mengandung informasi palsu/hoaks atau tidak dan menilai isi artikel yang mereka baca itu mengandung faktaatau mengandung opini, hal ini untuk memastikan artikel yang dibaca itu mengandung informasi palsu/hoaks atau tidak. Selain itu responden juga dapat menilai isi artikel yang mereka baca apabila informasi di dalamnya berbeda dengan judul artikel tersebut maka artikel itu cenderung informasi palsu/hoaks.

Hasil analisis deskriptif pada indikator identifikasi pada foto/gambar ditemukan bahwa kemampuan mahasiswa Bandung Raya dalam mengidentifikasi hoaks melalui penilai- 
annya pada foto/gambar berada dalam kategori tinggi, dengan hasil skor total sebesar 1.427 dari skor ideal 1.600 dan dalam presentase sebesar 71,35\%. Dalam hal ini para responden yaitu mahasiswa yang berasal dari Bandung Raya dikatakan mampu dalam mengidentifikasi hoaks melalui penilaian pada judul dalam sebuah artikel yang mereka dapatkan atau mereka baca di media sosial.

Dari penilaian pada foto/gambar menunjukan bahwa sebagian besar responden memperhatikan foto/gambar yang terdapat pada artikel untuk menilai keaslian informasi yang disajikan oleh artikel tersebut, hal ini untuk memastikan artikel yang dibaca itu mengandung informasi palsu/hoaks atau tidak. Selain itu menunjukan bahwa sebagian responden memperhatikan dan beranggapan bahwa foto/gambar ilustrasi merupakan hasil rekayasa dan apabila terdapat pada sebuah artikel cenderung informasi yang disajikannya mengandung informasi palsu/hoaks, menilai foto/gambar yang disajikan dalam sebuah artikel itu asli atau manipulasi, hal ini untuk memastikan artikel yang dibaca itu mengandung informasi palsu/hoaks atau tidak, menilai foto/gambar yang disajikan dalam sebuah artikel itu merupakan foto/gambar lama yang diperbaharui atau foto/gambar yang sesuai berdasarkan informasinya, hal ini untuk memastikan artikel yang dibaca itu mengandung informasi palsu/hoaks atau tidak.

Dalam penilaian pada foto/gambar juga menunjukan bahwa hanya sebagian kecil responden yang beranggapan bahwa artikel yang tidak terdapat foto/gambar merupakan artikel yang mengandung informasi palsu/hoaks.

Hasil analisis deskriptif pada indikator identifikasi pada sumber ditemukan bahwa kemampuan mahasiswa Bandung Raya dalam mengidentifikasi hoaks melalui penilaiannya pada sumber berada dalam kategori sangat tinggi, dengan hasil skor total sebesar 1.327 dari skor ideal 1.600 dan dalam presentase sebesar $85,75 \%$. Dalam hal ini para responden yaitu mahasiswa yang berasal dari Randung Raya dikatakan sangat mampu dalam mengidentifikasi hoaks melalui penilaian pada judul dalam sebuah artikel yang mereka dapatkan atau mereka baca di media sosial.

Dari penilaian pada sumber menunjukan bahwa sebagian besar responden menilai bahwa artikel yang berasal dari sumber yang tidak jelas asalnya merupakan artikel yang mengandung informasi palsu/hoaks karena berasal dari sumber yang tidak memiliki penanggung jawab, menilai bahwa artikel yang tidak memiliki sumber merupakan artikel yang mengandung informasi palsu/hoaks karena tidak memiliki penanggung jawab dan responden memperhatikan data yang berasal dari sumber yang dicantumkan dalam sebuah artikel untuk memastikan informasi di dalamnya buka informasi palsu/hoaks. Selain itu menunjukan bahwa sebagian besar responden mampu menilai sumber yang disajikan dalam sebuah artikel itu merupakan sumber yang terpercaya atau tidak, hal ini untuk memastikan artikel yang dibaca itu mengandung informasi palsu/hoaks atau tidak.

Berikut ini merupakan hasil rekapitulasi hasil analisis da- ta dari tanggapan responden mengenai indikator identifikasi hoaks.

TABEL 1 | Tanggapan Responden

\begin{tabular}{ll}
\hline Indikator & Total Skor \\
\hline Judul & 1.091 \\
\cline { 2 - 2 } & $68,19 \%$ \\
\hline Situs/Media Sosial & 1.523 \\
\cline { 2 - 2 } & $76,15 \%$ \\
\hline Konten & 1.317 \\
& $82,31 \%$ \\
\hline Foto/Gambar & 1.427 \\
\hline Sumber & $71,35 \%$ \\
\hline
\end{tabular}

Sumber: Data diolah

Berdasarkan perhitungan di atas diketahui bahwa nilai persentase yaitu sebesar 75,96\% dan berada dalam kategori tinggi yang artinya mahasiswa Bandung raya mampu mengidentifikasi hoaks melalui kelima indikator yaitu, judul, situs/media sosial, konten, foto/gambar dan sumber.

Dari 22 item pertanyaan didapatkan total skor yaitu 6.685 atau dengan persentase $75,96 \%$ sehingga masuk ke dalam kategori tinggi. Berikut adalah hasil akumulasi distribusi frekuensinya:

TABEL 2 | Distribusi Frekuensi Akumulasi Total Keseluruhan Indikator

\begin{tabular}{lllll}
\hline $\begin{array}{l}\text { AKUMULASI } \\
\text { INDIKATOR }\end{array}$ & \multicolumn{2}{c}{ TOTAL } & \multicolumn{2}{l}{ KESELURUHAN } \\
\hline \multirow{2}{*}{$\begin{array}{l}\text { KETERANGA } \\
\mathrm{N}\end{array}$} & $\mathrm{STS}$ & $\mathrm{TS}$ & $\mathrm{S}$ & $\mathrm{SS}$ \\
\cline { 2 - 5 } & $(1$ & $(2$ & $(3$ & $(4$ \\
& $\mathrm{POI}$ & $\mathrm{POI}$ & $\mathrm{POI}$ & $\mathrm{POI}$ \\
$\mathrm{N})$ & $\mathrm{N})$ & $\mathrm{N})$ \\
\hline JUDUL & 39 & 117 & 158 & 86 \\
\hline SITUS/MEDS & & & & \\
OS & 24 & 103 & 199 & 174 \\
\hline KONTEN & 7 & 56 & 174 & 163 \\
\hline FOTO & 26 & 142 & 211 & 121 \\
\hline SUMBER & 1 & 31 & 163 & 205 \\
\hline TOTAL POIN & 97 & 449 & 905 & 749 \\
\cline { 2 - 5 } & 546 & & 1.654 & \\
\hline JUMLAH & \multicolumn{5}{l}{} \\
PERSENTASE & $24,81 \%$ & & $75,19 \%$ & \\
\hline
\end{tabular}

Sumbe: Data diolah

Tabel di atas diperoleh berdasarkan tiap responden yang mengisi kuesioner sesuai poin yang ditentukan penelitian, dan didapatkan hasil bahwa $24,81 \%$ responden masuk kedalam kategori negatif yang berarti belom mampu menilai atau mengidentifikasi hoaks berdasarkan kelima indikator yang disediakan. Didapatkan juga $75,19 \%$ responden masuk kedalam kategori positif yang berarti mereka mampu mengid- 
entifikasi hoaks melalui kelima indikator yang disediakan.

Berdasarkan data yang diperoleh dari penyebaran kuesioner untuk mengetahui kemampuan mahasiswa bandung raya dalam mengidentifikasi hoaks bahwa mahasiswa dinilai sudah mampu menilai hoaks berdasarkan kelima indikator yang digunakan dalam penelitian.

Berdasarkan pengertian hoaks mahasiswa biasa mendapatkan informasi palsu itu melalui media sosial yang mereka gunakan, tetapi mahasiswa itu kebanyakan belum mampu membedakan hoaks dengan berita palsu. Mereka beranggapan bahwa hoaks dan berita palsu itu sama saja, tetapi dalam hal menilai sebuah artikel atau informasi yang mereka dapatkan, mereka sudah mampu untuk menilai informasi tersebut masuk ke dalam hoaks atau bukan.

Kelima indikator yang digunakan dalam penelitian untuk mengukur kemampuan mahasiswa dalam mengidentifikasi hoaks ini masuk juga kedalam teori ciri-ciri hoaks (Stanley, dewanpers.or.id dalam Harlaela, 2020). Untuk indikator penilaian yang pertama yaitu penilaian pada judul, mahasiswa akan dihadapkan dengan judul yang memiliki kata-kata proaktif yang biasanya merupakan judul yang dicantumkan untuk informasi palsu. Selain judul yang menggunakan kata-kata proaktif, biasanya juga judul dalam hoaks ini bersifat sensasional agar para pembacanya itu tertarik untuk mengunjungi artikel tersebut.

Untuk indikator penilaian yang kedua yaitu penilaian pada situs/media sosial, mahasiswa akan dihadapkan dengan ciri hoaks yang tidak memiliki redaksi pemberitaannya. Karena pada dasarnya hoaks itu merupakan sebuah informasi yang dapat dibuat oleh siapa saja pemilik akun di sebuah situs atau media sosial, hal ini menjadikan apabila mahasiswa membaca sebuah informasi palsu dari situs atau media sosial milik individu atau pribadi dan bukan merupakan situs atau media sosial milik jurnalistik online maka hal tersebut bisa di katakan hoaks (Harlaela, 2020).

Untuk indikator penilaian yang ketiga yaitu penilaiannya pada konten, mahasiswa lebih mudah menilai atau mengidentifikasi hoaks karena tentunya mereka akan membaca isi dari informasi tersebut, lalu apabila didapatkan sesuatu hal yang tidak berdasarkan fakta, memiliki unsur diskriminatif ataupun topik yang di angkatnya itu sudah kadaluwarsa. Karena mahasiswa sudah memiliki kemampuan intelektual apabila dihadapkan dengan informasi yang mereka dapatkan dari media sosial, terlebih lagi sudah banyaknya sosialisasi dari berbagai pihak tentang pentingnya memerangi hoaks.

Untuk indikator penilaian yang keempat yaitu penilaian pada foto/gambar, saat ini mahasiswa dapat dikatakan sebagai generasi milenial dan yang kehidupannya itu paling dekat dengan kecanggihan teknologi. Tentunya hal itu menjadikan mereka sudah tidak asing lagi dengan banyaknya aplikasi untuk mengedit sebuah foto/gambar, dari sini mahasiswa bisa menilai mana foto/gambar asli ataupun yang merupakan rekayasa. Selain itu mahasiswa dalam menilai se- buah hoaks berdasarkan foto/gambar yang tertera dalam artikel atau informasi yang mereka dapatkan jika dilihat dari ciri-ciri hoaks dalam penelitian ini bisa terdapat pada foto/gambar yang bersifat sensasional atau diskriminatif. Mahasiswa juga bisa menilai dari kesesuaian foto/gambar yang ditampilkan dengan konten atau isi yang terdapat dalam sebuah artikel atau informasi yang mereka dapatkan.

Yang terakhir indikator penilaian yang kelima yaitu penilaiannya pada sumber, mahasiswa dapat menilai dari ciri hoaks yang tidak adanya redaksi pemberitaan sama halnya seperti penilaian terhadap situs. Karena sumber merupakan sebuah bentuk penanggung jawab dari informasi atau artikel yang di unggah oleh situs/media sosial. Selain itu dalam menilai sumber yang menjadi ciri hoaks mahasiswa yang memiliki kemampuan berliterasi digital tentunya akan melakukan riset untuk mencari tahu kebenaran dari artikel atau informasi yang mereka dapatkan dari sumber yang kurang terpercaya atau bahkan tidak memiliki sumber (Rahadi, 2017).

Dalam berliterasi media digital mahasiswa biasa di hadapkan dengan berbagai jenis informasi yang mereka cari atau mereka dapatkan, disini kemampuan untuk berpikir kritis tentang apa yang mereka dapatkan itu diuji. Dalam hal penilaian terhadap sebuah informasi itu masuk ke dalam jenis hoaks atau bukan merupakan salah satu bagian dari kegiatan berpikir kritis pada literasi media digital. Karena pada dasarnya berliterasi itu kemampuan untuk dapat memahami segala sesuatu yang didapatkan dari media digital. Dalam penelitian Fauzi (2018), dengan adanya literasi media digital mahasiswa dapat melatih kemampuan intelektualnya apabila dihadapi dengan berbagai informasi yang mereka dapatkan sehingga kemampuan dalam menilai hoaks akan terus meningkat. Apabila mahasiswa mampu dalam menilai hoaks dan menghadapinya tentunya akan banyak manfaat yang bisa mereka terima, seperti mereka tidak akan mudah terbawa arus dan percata begitu saja kepada opini publik, tidak mudah tersesat atau salah dalam mengambil sebuah keputusan berdasarkan informasi yang didapatkan dari media sosial.

\section{KESIMPULAN}

Berdasarkan hasil penelitian dan analisa yang telah dilakukan, dapat disimpulkan bahwa kelima indikator yang disediakan dalam penelitian yaitu, identifikasi pada judul, identifikasi pada situs/media sosial, identifikasi pada konten, identifikasi pada foto/gambar dan identifikasi pada sumber didapatkan hasil bahwa mahasiswa bandung raya dapat dikatakan mampu menilai atau mengidentifikasi hoaks berdasarkan penilaiannya pada informasi atau artikel yang mereka dapatkan dari media sosial. Secara keseluruhan bahwa mahasiswa Bandung Raya mampu menilai informasi yang mereka baca atau atau mereka cerna itu merupakan informasi yang valid atau hoaks, sehingga diharapkan mereka tidak mudah tergiring arus pemberitaan yang menyesatkan dan tidak salah apabila mengambil keputusan berdasarkan informasi yang mereka dapatkan. 


\section{UCAPAN TERIMAKASIH}

Peneliti mengucapkan terimaksih kepada pembimbing peneliti yang telah banyak memberikan bimbingan dan arahan selama peneliti mengerjakan dan menyelesaikan penelitian ini. Terimakasih juga kepada mahasiswa bandung raya yang telah bersedia menjadi responden untuk penelitian ini.

\section{REFERENSI}

Annisa, Sekarwulan. Azzahra, Assyifa Amelia. Syifafasya, Nada. Safitri, Di. (2020). Penggunaan Media Sosial Terhadap Partisipasi Mahasiswa Ilmu Komunikasi UNJ dalam Menentukan Capres dan Cawapres 2019.pdf. Kanal : Jurnal Ilmu Komunikasi. https://doi.org/10.21070/kanalv8:2.139.

Aribowo, E. K. (2017). Menelusuri Jejak Hoaks Dari Kacamata Bahasa : 2016, $1-11$.

Aziz, Abdul. \& Wardi, M. (2018). Pemberitaan Media Tentang Transgender Perempuan di Madura.pdf. Kanal: Jurnal Ilmu Komunikasi. https://doi.org/10.21070/kanal.v\%vi\%i.1500.

Fatkhurahman. 2018. Kemapuan Mahasiswa Tempatan Menilai Berita Palsu atau "Hoax" dalam Media Sosial dalam Upaya Pengembangan Jiwa Kewirausahaan. Jurnal Benefita, 3(3), 417-426.

Fauzi., (2018). Memahami Literasi Media Baru dalam Penyebaran Informasi Hoax dan Hate Speech (Studi Fenomenologi Dosen Pengguna Facebook dan Whatsapp). PROMEDIA, Volume ke-4, No.2.

Febriani, Ririn Nur. (2020). Viral Info Pelayanan SIM Kolektif Tanpa Tes di Polres Cimahi, Simak Fakta-faktanya. Retrieved from pikiranrakyat.com: https://www.pikiran-rakyat.com/bandung-raya/pr-01346228/viral-infopelayanan-sim-kolektif-tanpa-tes-di-polres-cimahi-simak-faktafaktanya?page $=2$. Accessed on June 20, 2020

Fitriana, Kartika N. 2019. Persepsi Mahasiswa Universitas Lampung dalam Menilai Berita Hoax. Skripsi. Bandar Lampung: Universitas Lampung.

Gumgum, G., Justito, A., \& Nunik, M. (2017). Literasi Media: Cerdas Menggunakan Media Sosial Dalam Menanggulangi Berita Palsu (Hoax) Oleh Siswa Sma. Pengabdian Kepada Masyarakat, 1(1), 35-40. https://doi.org/1410 - 5675 .

Harlaela, A. (2020). Tanggapan Mahasiswa Fakultas Hukum dan FISIP Universitas Hasanuddin terhadap Berita Hoax Ratna Sarumpaet. Repository Universitas Hasanuddin Makassar.

Herlina, D. (2019). Literasi Media. Bandung: Remaja Rosdakarya.

Utiya, L C. (2017). Pemberitaan Hoax Perspektif Hukum Pidana Islam. AlJinayah: Jurnal Hukum Pidana Islam, 3(2), 325-348.

Liliweri, A. (2015). Komunikasi Antar Personal. Kencana Prenadamedia Group.

Meilinda, N. (2018). Social Media on Campus: Studi Peran Media Sosial sebagai Media Penyebaran Informasi Akademik pada Mahasiswa di Program Studi Ilmu Komunikasi FISIP UNSRI. The Journal of Society \& Media 2018, Vol. 2(1) 53-64.

Pakpahan, R. (2017). Analisis Fenomena Hoax Diberbagai Media. Konferensi Nasional Ilmu Sosial \& Teknologi (KNiST), 1(2013), 479-484. http://seminar.bsi.ac.id//knist/index.php/UnivBSI/article/view/184

Pddikti.kemdikbud.go.id. (2020). Statistik Perguruan Tinggi. Retrieved from pddikti.kemdikbud.go.id: https://pddikti.kemdikbud.go.id/pt

Rahadi, Dedi Rianto. (2017). Perilaku Pengguna dan Informasi Hoax di Media Sosial. Jurnal Manajemen dan Kewirausahaan. Unimer: Malang.

Riyanto, B., \& Hastuti, N. H. (2017). Literas Media Digital Mahasiswa Surakarta dalam Mensikapi Hoax di Media Sosial. Transformasi, I(33), 1-59.

Russo, Angelina, et al. (2008). Participatory Communication with Social Media. 21-31. http://www.amazon.de/dp/3706624397.

Simarmata, Janner, I., Muhammad, H., Muhammad Said. Limbong, Tonni. Albra, W. (2019). Hoaks dan Media Sosial: Saring Sebelum Sharing (A. Rikki (ed.)). Yayasan Kita Menulis.

Susilawati. (2017). Tanggapan Mahasiswa Ilmu Komunikasi Universitas Hasanuddin Terhadap Berita Palsu (Hoax) Pada Portal Berita.

Wirawan, R., \& Wibisono, M. B. (2017). Perancangan aplikasi sosial media untuk analisis berita hoax. 191-195.
Conflict of Interest Statement: The authors declare that the research was conducted in the absence of any commercial or financial relationships that could be construed as a potential conflict of interest.

Copyright (1) 2021 Kamilah and Atnan. This is an open-access article distributed under the terms of the Creative Commons Attribution License (CC BY). The use, distribution or reproduction in other forums is permitted, provided the original author(s) and the copyright owner(s) are credited and that the original publication in this journal is cited, in accordance with accepted academic practice. No use, distribution or reproduction is permitted which does not comply with these terms. 